\title{
Development of Accounting Curriculum Model Based on Industrial Revolution Approach
}

\author{
Meily Surianti \\ Accounting, Politeknik Negeri Medan \\ Jl. Almamater No.1 Kampus USU Medan 20155
}

\begin{abstract}
This study aims to develop an accounting curriculum with the Industry 4.0 approach. The specific target expected from this study is to produce curriculum designs that can be used as input in the revision of the curriculum in the Public Finance Accounting Program and the Accounting Study Program planned to be implemented in 2020. While the long-term target of the results of this study is the availability of a curriculum that can accommodate market needs, so that graduates of Accounting and Public Financial Accounting Study Programs have competitive competence and knowledge. Specific and long-term goals can be achieved by conducting deep interviews with several industrial and banking companies to identify the needs of the industrial world for accounting graduates. From the results of the study it was identified that there was a shift in the role of accountants, where this shift in role caused a shift in hardskill and soft skills that must be owned by an accountant. In addition, accommodating changes that occur can use two approaches, namely by inserting topics in existing subjects, or by creating new courses.
\end{abstract}

Keywords: Development, Curriculum, Industrial Revolution 4.0

DOI: $10.7176 /$ RJFA/11-2-12

Publication date: January $31^{\text {st }} 2020$

\section{Introduction}

Industry 4.0, also known as the smart industry, is considered the fourth industrial revolution. Originally initiated in Germany, the "Fourth Industrial Revolution", known as Industry 4.0, has attracted much attention in the latest literature. Industry 4.0 is defined as "the complex integration of physical machinery and devices with sensors and network software, used to predict, control and plan for better business and social outcomes" (Industrial Internet Consortium, 2017) or "a new level of organization and value chain management in the entire product life cycle "(Kagermann 2014) or" The collective term for technology and the concept of value chain organizations "(Hermann et al. 2016). The global industrial landscape has changed radically in recent years due to the rapid development and technological innovation in the manufacturing process ( Pereira and Romero 2017) This change is based on the adoption of new technologies for progressive automation of the production process, this is about innovative technology whose applications for industry will be developed day by day.

Industry 4.0 will make manufacturing more efficient and productive. By optimizing the plant, it directly increases yield. On the product side, it will also extract greater value from data for usage-based design and mass customization, which in turn will pave the way for new markets. At many levels, this will completely transform the business model into a results-based approach.

Automation, connectivity and embedded software can increase production line productivity by up to $30 \%$. The shift from product sales to sales of measurable results will redefine the entire structure of the industry. This is a shift to servicitisation, where companies use the Internet of Things (IoT) to find new ways to grow revenue and increase profits.

At the same time, as economists Erik Brynjolfsson and Andrew McAfee pointed out, the revolution can produce greater inequality, especially in its potential to disrupt the labor market. In lieu of automation for labor throughout the economy, the net transfer of workers to machinery can exacerbate the gap between capital returns and labor returns. On the other hand, it is also possible that the transfer of workers with technology will, in the aggregate, result in a net increase in safe and profitable employment.

Changes that occur in the technological environment affect almost all professions and require each profession to prepare themselves to face these changes, including the accounting profession. The American Institute of Certified Public Accountants (AICPA) website states that the accounting and financial profession will experience a decrease in work related to compliance and shift towards more consultative and advisory services caused by technological changes. It was also stated that technological change rapidly changes the work environment so that professionals 
must have more specific skills and competency demands related to increasingly high technological change (American Institute of Certified Public Accountants, 2018).

Based on research from Oxford University in 2013, it was stated that $47 \%$ in America risk being replaced by a computerized process (Frey \& Osborne, 2013), but if you look at the historical facts of the previous three industrial revolutions, new jobs will emerge with predictions of $65 \%$ of children those entering primary school will now work in a completely new type of work that does not currently exist. Even according to research conducted in Norway, there is no negative relationship between robotization and the possibility of getting a job.

In the era of the industrial revolution, universities are required to be able to adopt technology in learning, ranging from curriculum reorientation, mixed learning, and lifelong learning. The era of the industrial revolution also produced new literature that must be mastered by the younger generation, namely the data literature, technology literature, and humanities literature. Students must be able to utilize and process data, apply it to technology and understand how to apply that technology. Furthermore, humanities literature teaches students to be able to function and interact well with their peers and their environment (Kemenristekdikti, 2018).

Kemenristekdikti (2018) states that the various changes that occurred due to the Industrial Revolution 4.0 caused the need for adjustments to human work, machinery, processing, and technology in various professional fields including the accounting profession. The development of information technology and the increasingly massive use of big data requires accountants to continue to adjust. The shift that occurs in various fields of science requires accountants to change the way they work and practice in order to improve service quality and global expansion through online communication and the implementation of cloud computing technology. The accounting curriculum must also be adjusted so that it can meet the needs of the Industrial Revolution 4.0.

Accountants in the digital era must prepare themselves more seriously to anticipate the impact of technology, and need to master non-financial data such as data analysis, information technology development, and leadership skills. The effectiveness and efficiency of accountants' work can be improved by using big data and cloud computing. At this time big data and cloud computing technology has been developed by many companies. And to anticipate this development, the Ministry of Research, Technology and Higher Education encourages that the certification of accountants be accelerated by the IAI, so that accounting graduates will be equipped with certificates of expertise in accordance with the standards required by the industry to build a more accountable and goal-oriented ecosystem.

Changes in the curriculum in accordance with the development of the industrial revolution that is happening at this time, of course, requires supporting facilities that are not cheap, as well as up-to-date knowledge and skills that are also fundamental from the teaching staff. In addition to facilities, knowledge and skills, it is also necessary to change the mindset and outlook and analysis patterns in decision making.

Based on the phenomenon and presentation of the importance of curriculum adaptation to the 4.0 industrial revolution that is happening, researchers are interested in conducting research with the title 'Development of Accounting Curriculum Model Based on the Industrial Revolution Approach 4.0'.

\section{Literature Review}

\subsection{History of the Industrial Revolution}

At present, the creation of industrial value is shaped by development towards the fourth stage of industrialization, called Industry 4.0. Industry 4.0, referred to as the "Fourth Industrial Revolution", also known as "smart manufacturing", "internet industry" or "integrated industry", is currently a widely discussed topic. It is assumed that Industry 4.0 is thought to have the potential to influence the entire industry by changing the way goods are designed, produced, shipped, and paid for (Stock and Seliger 2016; Hofmann and Rüsch 2017). Industry 4.0 is the next step in a long development process, a revolution based on the use of cyber-physical systems (Grieco et al. 2017). In fact, the consequence of developing Internet Things and Big Data is the concept of Industry 4.0 as a consequence of sustainable development (Witkowski 2017).

The Industrial Revolution, which lasted from the 18th to 19th centuries, was the period in which most agricultural, rural communities in Europe and America became industrial and urban. Before the Industrial Revolution, which began in England in the late 1700s, manufacturing was often done in people's homes, using basic hand tools or machines. Industrialization marked a shift to powerful machinery, special purpose machinery, manufacturing and mass production. The iron and textile industry, together with the development of the steam engine, played a central role in the Industrial Revolution, which also witnessed an improvement in transportation, communication and banking systems. While industrialization brought increased volumes and variations in manufactured goods and improved living standards for some people, it also often resulted in grim work and living conditions for the poor 
and working class.

Revolution 2.0 formed the 1900s. supported by oil, cars, buses and airplanes as a new means of transportation. Telephone, TV, cinema and radio change communication and society. Manufacturing is far more productive with assembly lines, standard and specialized machine tools and stupid robots. Urbanization has led to the rise of the service economy.

The 3.0 Industrial Revolution took place during the first half of the 20th century, where two major world wars had begun one after another and the country's borders were destroyed. Therefore, industrialization and technological progress have slowed compared to the previous period. In this slowing process, negative economic developments such as the Global Crisis in 1929 occurred in many countries, especially the industrial countries of the first two revolutions. The effects of the crisis must be reduced so that the industry can continue its development, but this can only happen in the 1950s when World War II ended. The 1950s, when digital technology was developing, laid the foundation for the Third Industrial Revolution. Digital development mainly began with the production of Z1, an electrically driven mechanical calculator, to a computer that was very useful in the production process. Another important advance during the Third Industrial Revolution was the development of joint communication technology with supercomputers (Bosch, 2017).

\subsection{Industrial Revolution 4.0}

Industry 4.0 is the next step in a long development process, a revolution based on the use of cyber-physical systems (Grieco et al. 2017). In fact, the consequence of developing Internet Things and Big Data is the concept of Industry 4.0 as a consequence of sustainable development (Witkowski 2017). The main idea of Industry 4.0 was originally published by Kagermann based on cyber-physical manufacturing enabled systems and service innovations during the 2011 Hannover Fair event resulting from initiatives on high-tech strategies for 2020 (Lee et al. 2014; Zhou et al. 2015) .

Industry 4.0 provides a new paradigm for small and medium enterprise (SME) industry management. Supported by a growing number of new technologies, this concept appears more flexible and cheaper than traditional corporate information systems, such as ERP and MES. However, SMEs find themselves unprepared to meet these new opportunities regarding their production planning and control functions (Moeuf et al. 2018). The results show that strategic, operational, as well as environmental and social opportunities are positive drivers of Industry 4.0 implementation, while challenges related to competitiveness, future viability, and organizational and production compatibility hamper its progress.

In addition, it was shown that Industry 4.0's perception of opportunities and challenges, the first step towards implementing Industry 4.0, was highly dependent on companies with different characteristics.

Industry 4.0 is used for three interrelated factors:

1. Digitalization and integration of every simple technical-economic relationship in a complex technical economic complex network;

2. Digitalization of product and service offerings;

3. New Market Model.

All of these human activities are interconnected with many communication systems today. The most promising technologies are the Internet of Things (IoT), the Internet of Services (IoS), and the Internet of People (IoP).

\subsection{Industrial Revolution and Professional Accountant}

Accounting is considered as a profession that has existed since the birth of civilization and still survives to this day (Ozdolgan, 2017). Accounting as a business and management is always able to recruit themselves in the company in the face of various transformations, both transforming in the company and transforming the industry. Digitalization of the challenges of 'information literacy' as well as new assistance for accounting information providers. Big Data identification provides an opportunity for accounting and finance to take a more strategic role and help shape the future. Based on these needs, the curriculum for each major field of study in accounting education must be approved by these needs by creating an Accounting 4.0 education that will produce Accountants 4.0.

The American College and University Association, since 2007, states that there is a need for the next generation of people who have cross-disciplinary knowledge, high-level skills, and have social responsibility and 
relationships to use knowledge to solve complex problems. For this reason, universities must work closely with associations and companies to make revisions to the attributes needed to collect universities. These attributes must include knowledge and expertise that utilizes information technology in thinking, discussing and working procedures, analytical capabilities and knowledge related to information security. If the accountant initially only analyzed historical data, now the accountant is required to investigate a broader area, namely Big Data. Information technology, especially Big Data will reduce the time that accountants need to be collected, validate and process data and increase time to analyze, provide business insight and increase risk. This changes the role of accountants in the company (Stancuia \& Gheorge, 2017), (Ucar, Kizil, \& Oguz, 2018).Akuntan akan dituntut untuk berperan sebagai advisor dan terlibat dalam pengambilan keputusan (Henry \& Hicks, 2015). Oleh karena itu, akuntan akan meningkatkan pengetahuan dan spesialisasinya sehingga dapat memnuhi tuntutan perusahaan karena munculnya kebutuhan yang lebih tinggi atas non-financial reporting.

Various trends that can change the role of management accountants by utilizing Al-based technology include: (1) enterprise performance management (EPM), including business analysis; (2) predictive accounting; (3) improve management accounting methods; (4) IT management and shared service as a business; (5) Better skills and competencies in behavioral cost management, and (6) strategic planning (Meskovic, Garrison, Ghezal, Chen, 2018).

Related to Big Data, accountants must be able to distinguish critical critical data and insight from what is obtained from the data. Management accountants do not have to fully understand the structure of the database or carry out their own analysis of the data, but can collaborate with data scientists. The results of the data analytics must be understood by accountants and accountants must be able to determine how these results can increase value for business (Gamage, 2016).

In the field of auditing, with big data, auditors can perform data analytics so that they change the audit process at the transaction and general-ledger level, with new tools for extracting and visualizing data so that they can produce even better analyzes. Data analytics, if applied properly, can provide continuous auditing and help reduce operating risks so as to increase effectiveness and efficiency. In addition, from the results of data analytics, KAP can even enrich its work by providing consultations that can help its clients improve their competitive position. Another area that can utilize big data is forensic accounting services. This service requires investigative knowledge and expertise to collect, analyze and evaluate evidence to interpret and communicate findings. By mining big data using forensic data analytics tools, it is expected that the results will be better (Gamage, 2016).

The academic role as a guide to prepare the mental model of the community cannot be denied anymore because through its own way, academics are leaders who are tasked with being open the mind. The next lead task will be left by academics to practitioners (corporate leaders and state leaders) to open the heart and in the end, when an event occurs, it will create individuals who have been prepared for the open the will. If it has been prepared to deal with events with the right mental model, then when these events occur, individuals who are ready will be able to dance on the iceberg (Randolph, 2017)

Universities should be able to work closely with industry to ensure that graduates will have the expertise needed in the era of the industrial revolution 4.0, such as the use of AI-based and big data technology. The expertise that will be needed immediately in this era include:

1. The ability to analyze data for understanding of the factors that trigger business

2. Understanding of what is most needed by customers and how to track it

3. The ability to utilize new forms of data and use them for business decisions

4. The ability to interpret data to produce information that is more meaningful for decision makers.

Several associations and universities in various countries have implemented this change, for example: (1) The School of accounting at the raw colleges of business, Texas Tech University added Big data and data analytics courses to its curriculum; (2) St. Mary's University Greehey School of Business formed an accounting and data analytics degree program; (3) Malaysian Institute of Accountants requires accounting education to include IT, AIS, and system analysis and design topics in the curriculum of each tertiary institution (Gamage, 2016). But it is realized, cannot easily add independent courses such as big data without sacrificing other subjects. One possible solution is to add related topics in existing courses as in the following table: 
Table 1. Subjects and Topics Related to the Issue of the Industrial Revolution 4.0 (Gamage, 2016)

\begin{tabular}{|c|c|}
\hline Subject & Topic \\
\hline Business Statistics & $\begin{array}{l}\text { Data gathering techniques, data exploration, data summarization, data } \\
\text { analysis, data visualization, communication of analytical findings. }\end{array}$ \\
\hline Business Information Systems & $\begin{array}{l}\text { Advanced Databases, Information Retrieval, Advanced Data Mining } \\
\text { Applications, Predictive Analytics for Decision Making, Big Data } \\
\text { information management }\end{array}$ \\
\hline Management Accounting & $\begin{array}{l}\text { Application of Big Data to Competitor analysis, Big Data as a strategic } \\
\text { resource }\end{array}$ \\
\hline Accounting information system & $\begin{array}{l}\text { Business Intelligence, Enterprise Analytics Information search and } \\
\text { retrieval, Data mining, ERP Systems, Cybercrime, Data Management } \\
\text { Issues }\end{array}$ \\
\hline Finance & $\begin{array}{l}\text { Financial Analytics, Modelling and computation of financial risks, } \\
\text { Information Risk Management }\end{array}$ \\
\hline Auditing and Assurance & $\begin{array}{l}\text { Data Analytics in auditing, mine new sources of data, Data integrity, } \\
\text { Privacy, Safeguards, Cybersecurity, Design and evaluate IS Contols, } \\
\text { Overseeing fraud risk assessment. }\end{array}$ \\
\hline Forensic Accounting & $\begin{array}{l}\text { Big data, Benford's law, Financial analytics, Data analytics for fraud, } \\
\text { anomaly detection in forensics and security }\end{array}$ \\
\hline Taxation & $\begin{array}{l}\text { Indirect tax and big data, tax value and non-tax value form data that is } \\
\text { collected in the tax function, Visualize accounting data }\end{array}$ \\
\hline
\end{tabular}

\section{Purpose and Benefits of Research}

\subsection{Research Puproses}

The research objective is to obtain output in the form of an accounting curriculum design using the Industry 4.0 approach.

\subsection{Benefits of Research}

The results of this study are expected to contribute to the field of accounting, especially information technology and accounting. With the resulting curriculum design, it is expected that the Medan State Polytechnic accounting curriculum can better accommodate market needs.

\section{Methodology Research}

This research is a qualitative research with a descriptive model. Conceptually descriptive research is to explain the conditions that exist in the present or can be called describing a phenomenon, events, events that occur at the present time. The study was conducted in manufacturing companies, plantations, and banks.

The measurement and observation parameters used in this study are topics related to industry 4.0 issues stated by Gamage, (2016) as shown in table 1. These parameters are stated in the questionnaire, both open and closed questions. Data was collected by conducting deep interviews with middle and lower managers about the practice of using information technology in implementing business processes in their companies. Deep interviews are conducted using open and closed questions,

Questions are designed with reference to the topics raised by Gamage (2016) regarding topics that must be discussed in connection with the industrial revolution. Data from the results of the deep interviews were analyzed to be converted into the accounting curriculum, using the IQF reference. The subjects of this research are manufacturing companies, plantations, and banks. 


\section{Results and Discussion}

\subsection{Research Results}

Issues relating to the industrial revolution 4.0 can be accommodated into the curriculum with approaches, namely (1) by inserting new material into existing courses; and (2) by creating new subjects.

The biggest issues regarding the RI 4.0 curriculum are Block Chain, Big Data, Artificial Intelligence and Cloud Computing.

1. Blockchain is a digital data storage system that consists of many servers (multiserver). In blockchain technology, data created by one server can be replicated and verified by another server. Therefore, blockchain is often likened to a bank master cash book that contains all customer transaction data. However, this master ledger is accessible to all blockchain users and is not limited to authorized bank officers. With a blockchain, a transaction no longer needs to depend on one server, because the transaction will be replicated to the entire network. The nature of the network is peer to peer, blockchain users can also avoid various frauds that can occur due to data modification or hacking. On the blockchain, each block (a special area that accommodates all transaction changes) consists of a hash, which is the identity of a digital data. Now, each block contains a hash from the previous block. Each block in this system is interrelated and if there is an attempt to change the data in one block, then it must change the data in the other block. Each block protected by cryptography is interconnected to create a network. Initially the blockchain is used in the financial sector as an open, distributed and decentralized journal. Through the blockchain, intermediate transactions will be far more efficient than conventional transactions that still require the existence of intermediaries.

2. Big Data. Big Data is a general term for any collection of data sets that is so large and complex that it makes it difficult to handle or process if only using ordinary database management or traditional data processing applications. These data are usually unstructured.

3. Artificial intelligence. Artificial Intelligence is a science for designing, building, and constructing a machine (computer) or computer program to have intelligence like humans. Intelligence in this case is the ability to take action, or solve problems like humans use their intelligence. The scope of Artificial Intelligence research covers many aspects of human intelligence abilities such as reasoning, knowledge, planning, learning, natural language processing, to the ability to manipulate objects. Artificial Intelligence is expected to be a machine that truly has general intelligence like humans.

4. Cloud computing. Cloud computing is a combination of the use of computer technology (computing) in a network with internet-based development (cloud) which has the function to run programs or applications through computers connected at the same time, but not all that are connected via the internet using the cloud computing. Cloud system based computer technology is a technology that makes the internet a central server for managing data and also user applications. This technology allows users to run programs without installation and allows users to access their personal data through computers with internet access.

\subsubsection{Curriculum that Accommodates RI Issues 4.0}

Financial Accounting and Big Data: (1) Structured data and unstructured accounting data are integrated into the Accounting Information System. (2) Estimated fair value is obtained from the results of big data analysis.

1. Auditing and Big Data: Analyzing structured data and unstructured data to identify trends, habits and the potential for anomalous transactions.

2. Management Accounting and Big Data. Transform a comprehensive control and monitoring system

3. Accounting Standards and Big Data. Current accounting standards should focus on data rather than reporting performance.

4. Fraud Detection and Artificial Intelligence. Can process big data accounting (structured data and unstructured data) in a very large number so that it can recognize transaction patterns that have the potential for fraud / fraud.

5. Financial Crime Detection and Artificial Intelligence. AI can learn from errors and new cases so quickly that it can produce suspicious patterns of financial data, such as money laundering, the use of bank accounts for terrorism.

6. Cost Reduction and Artificial Intelligence. AI that is applied to the controller system will be able to 
produce cost reduction analysis from the predictive and preemptive analytics processes.

In addition to the above issues, issues relating to RI 4.0 are:

1. Automate transactional accounting processes, such as bookkeeping, data entry, and book closing periods.

2. Artificial Intelligence (AI) and advanced analytics, in auditing and risk assessment.

3. Robotic Process Automation (RPA), for work processes that require large and complex, monotonous and repetitive data management.

4. Data Science and Analytical Mindset

5. Famous technology, updates on the latest technological developments

6. Business knowledge \& industry insight

7. Behavior and psychology

\subsection{Discussion}

Based on input from several respondents, that the role of accountants at this time has undergone a shift, including: (1) With the automation process, the accountant is no longer related to the work of processing data transactions, but rather an analyst, who analyzes the output in the form of financial statements; (2) The use of an integrated system, for example the SAP application, causes the accountant not to be in contact with transaction data processing, but rather as a supervisor who ensures that the data inputted is valid and reliable data. This shift requires analytical skills and the ability to understand business processes in detail.

From the results of the above research, it can be proposed that topics related to RI 4.0, can be accommodated into existing courses, or made as stand-alone courses. As an example:

1. The topic Enterprise Enterprises Planning, suggested as a stand-alone course, given the very widespread use of this tool.

2. Topics about Artificial Intelligence, can be prepared in courses - subjects such as Accounting Information Systems, Financial Accounting, Management Accounting and others.

3. Topics regarding Big Data, can be inserted in the subjects of Financial Accounting, Audit, Management Accounting, and others.

4. Topics regarding Data Analytic, can be inserted in business statistics courses.

5. Topics about data warehouse and database management should be used as separate subjects.

6. Topics about block chains should be used as separate subjects.

7. Topics about cloud computing, can be inserted in the SIA course or SIA practice.

8. Topics regarding business processes, can be inserted in the SIA course.

\section{Conclusion and Suggestion}

\subsection{Conclusion}

From the results of the research and discussion above, it can be concluded that the progress of information technology, better known as RI 4.0, has caused shifts in the role of accountants, so that it must be responded quickly and appropriately by organizers of Higher Education, so graduates produced can meet the qualifications needed by the labor market. Curriculum changes can be done with two approaches, namely by inserting topics into existing courses, or by creating new courses.

\subsection{Suggestion}

From the results of the study it can be suggested that the Medan State Polytechnic Accounting Department immediately reforms the curriculum, including facilities and infrastructure as well as human resource capabilities.

\section{References}

Bhimani, A \& Leslie Willcocks (2014) Digitisation, 'Big Data' and the transformation of accounting information, Accounting 
and Business Research, 44:4, 469-490,

Bosch, Sanayi Ve Ticaret. 2017. A Brief History of Industry. http://www.sanayidegelecek.com/en/sanayi-4-0/tarihsel-gelisim/

Frey, and Osborne. 2012. "The Future of Employment: How Susceptible are Jobs to Computerisation", http://www.oxfordmartin.ox.ac.uk.pdf .

Gamage, P. (2016). Big Data: Are Accounting Educators Ready? Accounting and Management Information Systems, 15(3), 588-604.

Grieco, Antonio, Pierpaolo Caricato, Doriana Gianfreda, Matteo Pesce, Valeria Rigon, Luca Tregnaghi, and Adriano Voglino. 2017. An Industry 4.0 Case Study in Fashion Manufacturing. Procedia Manufacturing

Henry, B., \& Hicks, M. (2015). A Survey of Perspective on The Future of the Accounting Proffesion. CPA Journal, 10-14.

Hermann, Mario, Tobias Pentek, and Boris Otto. 2016. Design Principles for Industrie 4.0 Scenarios. Paper presented at 2016 49th Hawaii International Conference on System Sciences (HICSS), Koloa, HI, USA, January 5-8, pp. 3928-37.

Hofmann, Erik, and Marco Rüsch. 2017. Industry 4.0 and the current status as well as future prospects on logistics. Computers in Industry International Journal 89: 23-34.

Industrial Internet Consortium. 2017. A Global Industry First: Industrial Internet Consortium and Plattform Industrie 4.0 to Host Joint IIoT Security Demonstration at Hannover Messe 2017. Available online: https: //www.iiconsortium.org/press-room/04-20-17.htm (accessed on 23 July 2018).

Kagermann, Henning, Wolf-Dieter Lukas, and Wolfgang Wahlster. 2018. Industrie 4.0: Mit dem Internet der Dinge auf dem Weg zur $4 . \quad$ Industriellen Revolution-DFKI. Available online: https://www.dfki.de/web/presse/pressehighlights/industrie-4-0-mit-dem-internet-der-dinge-auf-demweg-zur-4industriellen-revolution/view

Kemenristekdikti. 2018c. Kebijakan Kemenristekdikti Menghadapi Globalisasi Pendidikan \& Revolusi Industri 4.0 [Press release].

Kemristekdikti. 2018a. Pengembangan Iptek dan Pendidikan Tinggi di Era Revolusi Industri 4.0. Retrieved https://www.ristekdikti.go.id/pengembangan-iptek-dan-pendidikan-tinggi-di-era-revolusiindustri-4-0

Lee, B. Bagheri, H-A Kao, “A Cyber-Physical Systems architecturefor Industry 4.0-based manufacturing” 2015, 3, 18-23.

Meskovic, E., Garrison, M., Ghezal, S., \& Chen, Y. Artificial Intelligence: Trend in Business and Implications for The Accounting Proffesion. Internal auditing, 5-13

Moeuf, Alexandre, Robert Pellerin, Samir Lamouri, Simon Tamayo-Giraldo, and Rodolphe Barbaray. 2018. The industrial management of SMEs in the era of Industry 4.0. International Journal of Production Research

Ozdogan, B. (2017, September 20th). The Future of Accounting Profession in an Era of Start-Ups, Accounting and Corporate Reporting. Doi: 10.5772/intechopen.69264

Pereira, A. C., and Fernando Romero. 2017. A review of the meanings and the implications of the Industry 4.0 concept. Procedia Manufacturing 13: 1206-14.

Randolph, B. W. (2017). Changing Steps: A Reflexive Journey in Transition. The Journal of Global Health Care Systems, 5(2), $1-15$.

Stanciua, V., \& Gheorghe, M. (2017). An Exploration of the Accounting Proffesion - The stream of Mobile Devices. Accounting and Management Information Systems, 46(3), 369-385

Stock, Tim, and Günther Seliger. 2016. Opportunities of Sustainable Manufacturing in Industry 4.0. Procedia CIRP 40: 53641.

Ucar, M., Kizil, C., \& Oguz, O. (2018). Problems of Accounting Professionals Residing In Instanbul and the Suggested Solutions. Emerging Markets Journal, 8(1), 18-30.

Witkowski, Krzysztof. 2017. Internet of Things, Big Data, Industry 4.0-Innovative Solutions in Logistics and Supply Chains Management. Procedia Engineering 182: 763-69.

Zhou, Keliang, Taigang Liu, and Lifeng Zhou. 2015. Industry 4.0: Towards future industrial opportunities and challenges. Paper presented at 2015 12th International Conference on Fuzzy Systems and Knowledge Discovery (FSKD), Zhangjiajie, China, August 15-17, pp. 2147-52. 